\title{
Analysis of the small-sided games in volleyball: an ecological approach
}

\section{Análise dos pequenos jogos no voleibol: uma abordagem ecológica}

\author{
Augusto Cézar Rodrigues Rocha ${ }^{1}$ \\ (D) https://orcid.org/ 0000-0003-3583-5676 \\ Henrique de Oliveira Castro 2,3 \\ (1D https://orcid.org/ 0000-0002-0545-164X \\ Auro Barreiros Freire ${ }^{4}$ \\ (1) https://orcid.org/ 0000-0001-5198-9363 \\ Bárbara Costa Faria ${ }^{1}$ \\ (D) https://orcid.org/ 0000-0003-2056-739X \\ Gustavo Palhares Mitre ${ }^{5}$ \\ (D) https://orcid.org/ 0000-0002-8330-9518 \\ Fabiano de Souza Fonseca ${ }^{6}$ \\ (D) https://orcid.org/ 0000-0002-9461-8797 \\ Cláudio Olívio Vilela Lima ${ }^{7}$ \\ (D) https://orcid.org/ 0000-0001-9867-0915 \\ Gustavo De Conti Teixeira Costa \\ (D) https://orcid.org/ 0000-0003-0911-8753
}

Abstract - The aim of the present study was to compare the tactical and technical behavior of beginner players in volleyball side-out between four distinct situations of reduced games with different area/player ratios: $4.5 \mathrm{~m}^{2}(3.0 \mathrm{~m} \times 3.0 \mathrm{~m}), 8.0 \mathrm{~m}^{2}(4.0 \mathrm{~m} \times 4.0 \mathrm{~m}), 10.58 \mathrm{~m}^{2}$ $(4.6 \mathrm{~m} \times 4.6 \mathrm{~m})$, and $13.52 \mathrm{~m}^{2}(5.2 \mathrm{~m} \times 5.2 \mathrm{~m})$. We analyzed 76 games played by 16 players with a mean age of $12.2 \pm 0.5$ years and experience of $1.2 \pm 0.8$ years of practice. Tactical and technical behavior was analyzed using an adaptation of the Game Performance Analysis Instrument (GPAI). The analysis was conducted for passing, setting and attacking according to the components related to technical adjustment, technical efficiency and decision-making. The results showed that players presented higher technical and tactical indexes in the passing and setting skills in $4.6 \mathrm{~m} \mathrm{x} 4.6 \mathrm{~m}$ and $5.2 \mathrm{~m} \mathrm{x} 5.2 \mathrm{~m}$ situations. Also, in the $3.0 \mathrm{~m} \mathrm{x} 3.0 \mathrm{~m}$ situation higher technical indexes were found for the attacking. No differences were found in the tactical behavior of attacking for tested situations. We conclude that the environmental constraints imposed by the small-sided games imply distinct technical and technical behaviors. Thus, the pedagogical strategy of using small-sided games for the teaching of volleyball for beginner players must be associated with the intended objectives for each basic volleyball skills.

Key words: Decision-making; Efficiency; Efficacy; Sport.

Resumo - O objetivo do presente estudo foi comparar o comportamento tático e técnico de jogadores iniciantes no voleibol no side-out de acordo com quatro situaçôes distintas de jogos reduzidos com diferentes relaçôes área/jogador: 4,5 m2 (3,0 $\mathrm{m} \times 3,0 \mathrm{~m}), 8,0 \mathrm{~m} 2(4,0 \mathrm{~m} \times 4,0 \mathrm{~m}), 10,58 \mathrm{~m} 2(4,6 \mathrm{~m}$ $x$ 4,6 m) e 13,52 m2 (5,2 $\mathrm{m} \times 5,2 \mathrm{~m})$. Foram analisados 76 jogos disputados por 16 jogadores com média de idade de 12,2 $\pm 0,5$ anos experiência de 1,2 $\pm 0,8$ anos de prática. O comportamento tático e técnico foi analisado por meio de uma a daptação do Game Performance Analysis Instrument. A análise foi realizada para a recepção, o levantamento e o ataque de acordo com os componentes relacionados ao ajuste técnico, eficiência técnica e a tomada de decisão. Os resultados mostraram que os jogadores apresentaram indices táticos e técnicos superiores nas habilidades de recepção e levantamento nas situaçôes de 4,6 $m \times 4,6 m$ e 5,2 $m \times 5,2 \mathrm{~m}$. Além disso, na situação de 3,0 $m \times 3$ 3,0 $m$ foram encontrados indices técnicos mais elevados para o ataque. Não foram encontradas diferenças no comportamento tático do ataque para as situaçôes analisadas. Concluímos que as restrições ambientais, impostas pelos pequenos jogos, implicam em comportamentos táticos e técnicos distintos. Assim, a estratégia pedagógica de utilização de pequenos jogos para o ensino do voleibol para jogadores iniciantes deve estar associada aos objetivos pretendidos para cada uma das habilidades básicas do voleibol.

Palavras-chave: Tomada de decisão; Eficiência; Eficácia; Esporte.
1 Universidade Federal de Goiás. Goiânia, GO. Brasil

2 Instituto de Educação Superior de Brasília. Brasília, DF. Brasil

3 Faculdade Anhanguera de Ciência e Tecnologia de Brasília. Brasília, DF. Brasil

4 Centro Universitário UNA de Belo Horizonte. Belo Horizonte, MG. Brasil

5 Centro Universitário Estácio de Belo Horizonte. Belo Horizonte, MG. Brasil

6 Universidade Federal Rural de Pernambuco. Recife, PE. Brasil.

7 Minas Tênis Clube. Belo Horizonte, MG. Brasil.

Received: November 22, 2019 Accepted: July 29, 2020

How to cite this article Rocha ACR, Castro HO, Freire AB, Faria BC, Mitre GP, Fonseca FS, Lima COV, Costa GDCT. Analysis of the smallsided games in volleyball: an ecological approach. Rev Bras Cineantropom Desempenho Hum 2020, 22:e70184. DOl: http://dx.doi.org/10.1590/19800037.2020v22e70184

Copyright: This work is licensed under a Creative Commons Attribution 4.0 International License. 


\section{INTRODUCTION}

Small-sided games (SSGs) are considered effective strategies for sports teaching, as they reduce the number of players ${ }^{1}$ and increase the number of tactical and technical actions taken by players ${ }^{2}$. Thereby, SSGs require players to adapt to new game scenarios and enhance additional tactical experience in distinct situational contexts ${ }^{3,4}$. In volleyball, players relate to the environment through their senses. The information that comes from the environment to provide a solution (mental and motor) for the game problem relates to their tactical knowledge and accord to the player's experience ${ }^{5}$.

In this sense, such teaching and training strategy provides an increase in physical, technical and tactical performance, with a high motivational level, since it promotes the integration of decision-making processes and other intervening factors to performance ${ }^{6}$. In addition, differences in tactical and technical behavior have been observed according to the sport (i.e. soccer $^{7,8}$, basketball ${ }^{9}$, handball ${ }^{10}$, hockey $\left.{ }^{11}\right)$, as their specificities demand different solutions within the rules of action.

The SSGs enable the identification of the skill level of the players ${ }^{12}$, as well as proposing effective interventions in the teaching and learning process in a contextualized manner ${ }^{13}$. Thus, it seems that this kind of pedagogical approach is effective in teaching children in physical education classes $^{14}$, as well as in high performance training ${ }^{6}$. This fact is due to the SSGs to increase the knowledge of the game, as it allows the active participation in conditioned formats of practice, besides reinforcing the specificity of tactical-technical behavior ${ }^{15}$. In this context, changes regarding the number of participants, court size, rule adaptation, action possibilities, decision-making, among others, should be analyzed and considered according to the proposed objective for the activity and the player's performance level ${ }^{6,15}$.

However, although SSGs are effective in different sports contexts, it is not clear how reduced games influence tactical-technical behaviors and how these are altered by task-specific ${ }^{16}$. Moreover, it is not fully understood in the literature how environmental restrictions, specifically game space, affect the tactical-technical behavior of volleyball players in SSGs. Thus, the aim of the present study was to compare the tactical-technical behavior on side-out, i.e. passing, setting and attacking, between four distinct situations of reduced volleyball games with novice players. We chose to analyze the side-out, as this game complex shows greater effectiveness in volleyball games ${ }^{17,18}$.

\section{METHOD}

\section{Sample}

The sample consisted of 979 side-out actions resulting from the analysis of 76 small-sided games played by 16 players with an average age of $12.2 \pm$ 0.5 years and an average of $1.2 \pm 0.8$ years of practical experience. Players participated in a school volleyball team and trained at a frequency of 3 times 
a week lasting 90 minutes each training session. The study was approved by the University's Research Ethics Committee under number 2.394.440.

\section{Experimental Design}

Players were split into pairs using ranking as a criterion for their constitution. The highest ranked player paired the worst ranked player, and so on. The ranking was performed by three experienced volleyball coaches (more 10 years of experience in deliberate practice with coach and with experience in national and international tournaments) and the players technical-tactical levels were considered, adopting the definition proposed by Erickson et al. ${ }^{19}$.

Each pair played between two and three games on each intervention day with a minimum interval of 10 minutes between each game. The intervention took place for 3 days for each pair respecting a minimum interval of $48 \mathrm{~h}$ between each session. The games took place under 4 different playing space conditions: $3.0 \mathrm{~m} \times 3.0 \mathrm{~m}\left(9 \mathrm{~m}^{2}\right), 4.0 \mathrm{~m} \times 4.0 \mathrm{~m}\left(16 \mathrm{~m}^{2}\right), 4.6 \mathrm{~m} \times 4.6$ $\mathrm{m}\left(21.16 \mathrm{~m}^{2}\right)$, and $5.2 \mathrm{~m} \times 5.2 \mathrm{~m}\left(27.04 \mathrm{~m}^{2}\right)$.

\section{Technical-tactical behavior assessment}

The technical-tactical behavior of the players during the games was evaluated through the instrument validated by Collet et al. ${ }^{20}$. The analysis was conducted for the passing, setting and attacking, considering the components related to technical adjustment, technical efficiency and decisionmaking. According to Porath et al. ${ }^{21}$, the performance analysis observation criteria can be understood as follows: adjustment as movements and postures performed before, during and after contact with the ball; efficiency characterized as technical execution; and choices and decisions that are made in the game defined as decision-making.

\section{Data Collection Procedure}

The games were filmed from the top perspective with a camera positioned behind the court approximately $4 \mathrm{~m}$ above the ground and $4 \mathrm{~m}$ from the bottom line. A Sony camera with 1080p HD definition and a frequency rate of $60 \mathrm{~Hz}$ was used.

\section{Data analysis}

Descriptive data analysis used frequencies, percentages, means and standard deviations. The comparison of the game situations by means of the one-way variance test (Anova) and Bonferroni's post hoc test was used in adjustment and efficiency, as well as the chi-square test $(\chi 2)$ and the power of the phi effect $(\phi)$ for the analysis of categorical variables (decision-making) and significance value in both cases was $\mathrm{p}<0.05$. To calculate the reliability $20 \%$ of the actions were reanalyzed, exceeding the reference value of $10 \%{ }^{22}$. The intra-observer values were between 0.93 and 0.98 and the inter-observer values between 0.89 and 0.98. Data were analyzed in the Statistical Package Social Science (SPSS) 23.0. 


\section{RESULTS}

Results are presented for each volleyball skill according to the parameters of adjustment, efficiency and decision-making. In analyzing passing (Table 1), the one-way ANOVA identified that there was difference in item 1 of the passing adjustment. $[F(3,974)=30,861 ; p<0,001]$. Post hoc test showed that the $3.0 \mathrm{~m} \times 3.0 \mathrm{~m}$ condition differed from the others. In addition, it was observed that there was a difference in item $1[F(3,974)=29,433 ; \mathrm{p}<0,001]$, item $2[\mathrm{~F}(3,974)=17,807 ; \mathrm{p}<0,001]$, and item $3[\mathrm{~F}(3,974)=3,279 ; \mathrm{p}<0,02]$ of passing efficiency. Post hoc test showed that in item 1 , the $4.0 \mathrm{~m} \mathrm{x} 4.0 \mathrm{~m}$ condition differed from the others, and the $3.0 \mathrm{~m} \times 3.0 \mathrm{~m}$ condition differed from $4.6 \mathrm{~m}$ $\mathrm{x} 4.6 \mathrm{~m}$; in item 2 , the condition $3.0 \mathrm{~m} \times 3.0 \mathrm{~m}$ differed from the other conditions; and in item 3 , the condition $3.0 \mathrm{~m} \times 3.0 \mathrm{~m}$ differed from $4.6 \mathrm{~m} \mathrm{x} 4.6 \mathrm{~m}$.

Table 1. Comparison of adjustment and passing efficiency in relation to the playing condition.

\begin{tabular}{|c|c|c|c|c|c|}
\hline & & Aspects analyzed & Condition & Mean \pm SD & $p$ \\
\hline \multirow{12}{*}{ Passing } & \multirow{12}{*}{ Adjustment } & \multirow{4}{*}{$\begin{array}{l}\text { Item 1: Moves to occupy posi- } \\
\text { tion in the likely fall of the ball. }\end{array}$} & $3,0 \mathrm{~m} \times 3,0 \mathrm{~m}$ & $0,29 \pm 0,46$ & \multirow{4}{*}{$0,001^{*}$} \\
\hline & & & $4,0 \mathrm{~m} \times 4,0 \mathrm{~m}$ & $0,04 \pm 0,21$ & \\
\hline & & & $4,6 \mathrm{~m} \times 4,6 \mathrm{~m}$ & $0,12 \pm 0,33$ & \\
\hline & & & $5,2 \mathrm{~m} \times 5,2 \mathrm{~m}$ & $0,13 \pm 0,34$ & \\
\hline & & \multirow{4}{*}{$\begin{array}{l}\text { Item } 2 \text { : Puts in expectation } \\
\text { position and adjusts its position } \\
\text { according to the proximity of the } \\
\text { lateral lines. }\end{array}$} & $3,0 \mathrm{~m} \times 3,0 \mathrm{~m}$ & $0,30 \pm 0,46$ & \multirow{4}{*}{0,457} \\
\hline & & & $4,0 \mathrm{~m} \times 4,0 \mathrm{~m}$ & $0,27 \pm 0,44$ & \\
\hline & & & $4,6 \mathrm{~m} \times 4,6 \mathrm{~m}$ & $0,34 \pm 0,47$ & \\
\hline & & & $5,2 \mathrm{~m} \times 5,2 \mathrm{~m}$ & $0,29 \pm 0,46$ & \\
\hline & & \multirow{4}{*}{$\begin{array}{l}\text { Item 3: After receiving, moves to } \\
\text { perform the next action (attack- } \\
\text { ing or coverage). }\end{array}$} & $3,0 \mathrm{~m} \times 3,0 \mathrm{~m}$ & $0,01 \pm 0,11$ & \multirow{4}{*}{0,255} \\
\hline & & & $4,0 \mathrm{~m} \times 4,0 \mathrm{~m}$ & $0,01 \pm 0,07$ & \\
\hline & & & $4,6 \mathrm{~m} \times 4,6 \mathrm{~m}$ & $0,02 \pm 0,14$ & \\
\hline & & & $5,2 \mathrm{~m} \times 5,2 \mathrm{~m}$ & $0,00 \pm 0,00$ & \\
\hline \multirow{12}{*}{ Passing } & \multirow{12}{*}{ Efficiency } & \multirow{4}{*}{$\begin{array}{l}\text { Item 1: Semi-flexed lower limbs } \\
\text { resting on the floor at the mo- } \\
\text { ment of contact. }\end{array}$} & $3,0 \mathrm{~m} \times 3,0 \mathrm{~m}$ & $0,73 \pm 0,45$ & \multirow{4}{*}{$0,001^{*}$} \\
\hline & & & $4,0 \mathrm{~m} \times 4,0 \mathrm{~m}$ & $0,89 \pm 0,30$ & \\
\hline & & & $4,6 \mathrm{~m} \times 4,6 \mathrm{~m}$ & $0,58 \pm 0,50$ & \\
\hline & & & $5,2 \mathrm{~m} \times 5,2 \mathrm{~m}$ & $0,62 \pm 0,49$ & \\
\hline & & \multirow{4}{*}{$\begin{array}{l}\text { Item 2: Positions the body } \\
\text { behind the ball and contacts } \\
\text { the ball in the middle of the } \\
\text { supports. }\end{array}$} & $3,0 \mathrm{~m} \times 3,0 \mathrm{~m}$ & $0,78 \pm 0,42$ & \multirow{4}{*}{$0,001^{*}$} \\
\hline & & & $4,0 \mathrm{~m} \times 4,0 \mathrm{~m}$ & $0,95 \pm 0,22$ & \\
\hline & & & $4,6 \mathrm{~m} \times 4,6 \mathrm{~m}$ & $0,90 \pm 0,30$ & \\
\hline & & & $5,2 m \times 5,2 m$ & $0,92 \pm 0,27$ & \\
\hline & & \multirow{4}{*}{$\begin{array}{l}\text { Item 3: Contact the ball on } \\
\text { the platform formed by the } \\
\text { forearms with the upper limbs in } \\
\text { extension (forearm) or contact } \\
\text { the ball above and in front of } \\
\text { forehead level (hands setting). }\end{array}$} & $3,0 \mathrm{~m} \times 3,0 \mathrm{~m}$ & $0,95 \pm 0,22$ & \multirow{4}{*}{$0,02^{\star}$} \\
\hline & & & $4,0 \mathrm{~m} \times 4,0 \mathrm{~m}$ & $0,97 \pm 0,16$ & \\
\hline & & & $4,6 \mathrm{~m} \times 4,6 \mathrm{~m}$ & $0,99 \pm 0,09$ & \\
\hline & & & $5,2 \mathrm{~m} \times 5,2 \mathrm{~m}$ & $0,97 \pm 0,17$ & \\
\hline
\end{tabular}

Note. * Statistical difference between conditions $p<0.05$.

The chi-square test showed that there was an association between decision-making at passing and the game condition $(\chi 2=94,625 ; \mathrm{p}<0,001$; $\phi=0,31)$. There was a positive association between "sending the ball directly to the opposing court" and the $3.0 \mathrm{~m} \times 3.0 \mathrm{~m}$ playing condition (Adjusted Residuals [AR]: 2.7); between "keeping the ball in play in the team itself, but without direction (puts the ball up) and the condition $4.0 \mathrm{~m} \times 4.0 \mathrm{~m}$ 
(AR: 5,3); and between "anticipating and directing the ball into the lifting zone" and condition 4.6m x 4.6m (AR: 5,6) and 5.2m x 5.2m (AR: 5,8). On the other hand, there was a negative association between "keeping the ball in play in the team itself, but without direction (puts the ball up) and the playing conditions $4.6 \mathrm{~m} \times 4.6 \mathrm{~m}$ (AR: - 2.5) and $5.2 \mathrm{~m} \times 5.2 \mathrm{~m}$ (AR: $3.2)$; and between "anticipating and directing the ball to the setting zone" and the $4.0 \mathrm{~m} \times 4.0 \mathrm{~m}$ condition (AR: -7.0 ).

Considering the setting, the one-way Anova identified difference in the following adjustment items (Table 2): item 1 [F (3,713) = 14,848; $\mathrm{p}<0.001]$, in which the post hoc test showed that the $4.0 \mathrm{~m} \mathrm{x} 4.0 \mathrm{~m}$ condition differed from the others, as well as the $5.2 \mathrm{mx} 5.2 \mathrm{~m}$ condition; items $2[\mathrm{~F}(3.713)=$ 47.880; $\mathrm{p}<0.001]$ and $3[\mathrm{~F}(3.713)=6.858 ; \mathrm{p}<0.001]$, where the post hoc test showed that the $4.6 \mathrm{~m} \times 4.6 \mathrm{~m}$ and $5.2 \mathrm{~m} \times 5.2 \mathrm{~m}$ conditions differed from the others in both respects.

Regarding the setting efficiency, the following differences were identified: item $2[\mathrm{~F}(3,712)=19,319 ; \mathrm{p}<0.001]$, in which the post hoc test showed that the $4.6 \mathrm{~m} \times 4.6 \mathrm{~m}$ and $5.2 \mathrm{~m} \times 5.2 \mathrm{~m}$ conditions differed from the other conditions; item $3[\mathrm{~F}(3.712)=19.319 ; \mathrm{p}<0.001]$, where the post hoc test showed that the $3.0 \mathrm{~m} \times 3.0 \mathrm{~m}$ condition differed from the $4.6 \mathrm{~m} \mathrm{x}$ $4.6 \mathrm{~m}$ and $5.2 \mathrm{~m} \times 5.2 \mathrm{~m}$ conditions.

Table 2. Comparison of adjustment and setting efficiency in relation to the playing condition.

\begin{tabular}{|c|c|c|c|c|}
\hline & Aspects analyzed & Condition & Mean \pm SD & $p$ \\
\hline \multirow{12}{*}{ Setting Adjustment } & \multirow{4}{*}{$\begin{array}{l}\text { Item 1: Moves quickly to the } \\
\text { lift position. }\end{array}$} & $3,0 \mathrm{~m} \times 3,0 \mathrm{~m}$ & $0,15 \pm 0,362$ & \multirow{4}{*}{$0,001^{*}$} \\
\hline & & $4,0 \mathrm{~m} \times 4,0 \mathrm{~m}$ & $0,03 \pm 0,175$ & \\
\hline & & $4,6 \mathrm{~m} \times 4,6 \mathrm{~m}$ & $0,14 \pm 0,353$ & \\
\hline & & $5,2 \mathrm{~m} \times 5,2 \mathrm{~m}$ & $0,27 \pm 0,446$ & \\
\hline & \multirow{4}{*}{$\begin{array}{l}\text { Item 2: Adjusts body position } \\
\text { according to the trajectory of } \\
\text { the ball. }\end{array}$} & $3,0 \mathrm{~m} \times 3,0 \mathrm{~m}$ & $0,97 \pm 0,158$ & \multirow{4}{*}{$0,001^{*}$} \\
\hline & & $4,0 \mathrm{~m} \times 4,0 \mathrm{~m}$ & $0,98 \pm 0,155$ & \\
\hline & & $4,6 \mathrm{~m} \times 4,6 \mathrm{~m}$ & $0,70 \pm 0,459$ & \\
\hline & & $5,2 \mathrm{~m} \times 5,2 \mathrm{~m}$ & $0,69 \pm 0,465$ & \\
\hline & \multirow{4}{*}{$\begin{array}{l}\text { Item 3: Stabilizes body posi- } \\
\text { tion as a function of attacking } \\
\text { completion zone (frontal plane } \\
\text { setting). }\end{array}$} & $3,0 \mathrm{~m} \times 3,0 \mathrm{~m}$ & $0,39 \pm 0,489$ & \multirow{4}{*}{$0,001^{*}$} \\
\hline & & $4,0 \mathrm{~m} \times 4,0 \mathrm{~m}$ & $0,44 \pm 0,498$ & \\
\hline & & $4,6 \mathrm{~m} \times 4,6 \mathrm{~m}$ & $0,57 \pm 0,497$ & \\
\hline & & $5,2 \mathrm{~m} \times 5,2 \mathrm{~m}$ & $0,64 \pm 0,483$ & \\
\hline \multirow{12}{*}{ Setting Efficiency } & \multirow{5}{*}{$\begin{array}{l}\text { Item 1: Contact the ball on } \\
\text { the forearm platform with the } \\
\text { extended upper limbs (forearm } \\
\text { setting) or contact the ball } \\
\text { above and in front of forehead } \\
\text { level (hands setting). }\end{array}$} & $3,0 \mathrm{~m} \times 3,0 \mathrm{~m}$ & $0,95 \pm 0,212$ & \multirow{4}{*}{0,991} \\
\hline & & $4,0 \mathrm{~m} \times 4,0 \mathrm{~m}$ & $0,95 \pm 0,216$ & \\
\hline & & $4,6 \mathrm{~m} \times 4,6 \mathrm{~m}$ & $0,96 \pm 0,202$ & \\
\hline & & $5,2 \mathrm{~m} \times 5,2 \mathrm{~m}$ & $0,95 \pm 0,222$ & \\
\hline & & $3,0 \mathrm{~m} \times 3,0 \mathrm{~m}$ & $0,06 \pm 0,230$ & \multirow{4}{*}{$0,001^{*}$} \\
\hline & \multirow{3}{*}{$\begin{array}{l}\text { Item 2: Coordinates flexion } \\
\text { and extension of the upper and } \\
\text { lower limbs. }\end{array}$} & $4,0 \mathrm{~m} \times 4,0 \mathrm{~m}$ & $0,01 \pm 0,102$ & \\
\hline & & $4,6 \mathrm{~m} \times 4,6 \mathrm{~m}$ & $0,19 \pm 0,398$ & \\
\hline & & $5,2 \mathrm{~m} \times 5,2 \mathrm{~m}$ & $0,17 \pm 0,375$ & \\
\hline & \multirow{4}{*}{$\begin{array}{l}\text { Item 3: At the moment of } \\
\text { contact, directs the body } \\
\text { position to the end zone of the } \\
\text { attacking. }\end{array}$} & $3,0 \mathrm{~m} \times 3,0 \mathrm{~m}$ & $0,35 \pm 0,477$ & \multirow{4}{*}{$0,001^{*}$} \\
\hline & & $4,0 \mathrm{~m} \times 4,0 \mathrm{~m}$ & $0,45 \pm 0,498$ & \\
\hline & & $4,6 \mathrm{~m} \times 4,6 \mathrm{~m}$ & $0,50 \pm 0,502$ & \\
\hline & & $5,2 \mathrm{~m} \times 5,2 \mathrm{~m}$ & $0,60 \pm 0,493$ & \\
\hline
\end{tabular}

Note. * ${ }^{*}$ tatistical difference between conditions $p<0.05$. 
The chi-square test showed that there was an association between decision-making at setting and the game condition $(\chi 2=15.229 ; \mathrm{p}<0.002$; $\phi=0.15)$. A positive association was observed between "Keep the ball in play in the team itself, but without direction (put the ball up)" and the condition $3.0 \mathrm{~m} \times 3.0 \mathrm{~m}$ (AR: 3.0 ) and between "imposing strength and proper direction for the ball to reach the attacking player." and the $4.0 \mathrm{~m}$ $\mathrm{x} 4.0 \mathrm{~m}$ condition (AR: 3.7 ). On the other hand, there was a negative association between "Keep the ball in play in the team itself, but without direction (put the ball up)" and the $4.0 \mathrm{~m} \times 4.0 \mathrm{~m}$ condition (AR: -3.7 ) and between "impose adequate force and direction so that the ball reaches the attacking player" and condition $3.0 \mathrm{~m} \times 3.0 \mathrm{~m}$ (AR: -3.0).

Considering the attacking, the one-way Anova identified difference in the following adjustment items (Table 3): $[\mathrm{F}(3,839)=21,266 ; \mathrm{p}<0,001]$, in which the post hoc test showed that the $3.0 \mathrm{~m} \times 3.0 \mathrm{~m}$ condition differed from the others, item $2[F(3,839)=10,648 ; p<0,001]$, where the post hoc test showed that the $4.6 \mathrm{~m} \times 4.6 \mathrm{~m}$ and $5.2 \mathrm{~m} \times 5.2 \mathrm{~m}$ conditions differed from the others conditions.

Regarding the attacking efficiency differences were found only in item $1[F(3,839)=18,659 ; \mathrm{p}<0,001]$. Post hoc test showed that the $3,0 \mathrm{~m} \times 3,0 \mathrm{~m}$ condition differed from the other conditions and 4,6m x 4,6m condition differed from the $5,2 \mathrm{~m} \times 5,2 \mathrm{~m}$.

The chi-square test showed that there was no association $(\chi 2=10,251 ; \mathrm{p}$ $=0.114 ; \phi=0.11)$ between attacking decision-making and game condition.

Table 3. Comparison of adjustment and attacking efficiency in relation to the playing condition.

\begin{tabular}{|c|c|c|c|c|}
\hline & Aspects analyzed & Condition & Mean \pm SD & $p$ \\
\hline \multirow{3}{*}{ Adjustment } & $\begin{array}{l}\text { Item 1: Waits for the lift to } \\
\text { begin the approach phase of } \\
\text { the spike (goes to the starting } \\
\text { point of attacking). }\end{array}$ & $\begin{array}{l}3,0 \mathrm{~m} \times 3,0 \mathrm{~m} \\
4,0 \mathrm{~m} \times 4,0 \mathrm{~m} \\
4,6 \mathrm{~m} \times 4,6 \mathrm{~m} \\
5,2 \mathrm{~m} \times 5,2 \mathrm{~m}\end{array}$ & $\begin{array}{l}0,17 \pm 0,39 \\
0,01 \pm 0,17 \\
0,06 \pm 0,24 \\
0,00 \pm 0,10\end{array}$ & $0,001^{*}$ \\
\hline & $\begin{array}{l}\text { Item 2: Adjusts the plang } \\
\text { phase according to the trajec- } \\
\text { tory and speed of ball. }\end{array}$ & $\begin{array}{l}3,0 \mathrm{~m} \times 3,0 \mathrm{~m} \\
4,0 \mathrm{~m} \times 4,0 \mathrm{~m} \\
4,6 \mathrm{~m} \times 4,6 \mathrm{~m} \\
5,2 \mathrm{~m} \times 5,2 \mathrm{~m}\end{array}$ & $\begin{array}{l}0,17 \pm 0,38 \\
0,18 \pm 0,39 \\
0,06 \pm 0,24 \\
0,00 \pm 0,00\end{array}$ & $0,001^{*}$ \\
\hline & $\begin{array}{l}\text { Item } 3 \text { : Adjusts the movement } \\
\text { speed of the attack arm as } \\
\text { a function of the opposing } \\
\text { block. }\end{array}$ & $\begin{array}{l}3,0 \mathrm{~m} \times 3,0 \mathrm{~m} \\
4,0 \mathrm{~m} \times 4,0 \mathrm{~m} \\
4,6 \mathrm{~m} \times 4,6 \mathrm{~m} \\
5,2 \mathrm{~m} \times 5,2 \mathrm{~m}\end{array}$ & $\begin{array}{l}0,01 \pm 0,09 \\
0,01 \pm 0,10 \\
0,01 \pm 0,09 \\
0,01 \pm 0,10\end{array}$ & 0,994 \\
\hline \multirow{3}{*}{ Attacking } & $\begin{array}{l}\text { Item 1: Positions the opposite } \\
\text { foot of the dominant upper } \\
\text { limb slightly forward. }\end{array}$ & $\begin{array}{l}3,0 \mathrm{~m} \times 3,0 \mathrm{~m} \\
4,0 \mathrm{~m} \times 4,0 \mathrm{~m} \\
4,6 \mathrm{~m} \times 4,6 \mathrm{~m} \\
5,2 \mathrm{~m} \times 5,2 \mathrm{~m}\end{array}$ & $\begin{array}{l}0,31 \pm 0,46 \\
0,12 \pm 0,33 \\
0,17 \pm 0,38 \\
0,04 \pm 0,19\end{array}$ & $0,001^{*}$ \\
\hline & $\begin{array}{l}\text { Item 2: Coordinates flexion } \\
\text { and extension of upper and } \\
\text { lower limbs. }\end{array}$ & $\begin{array}{l}3,0 \mathrm{~m} \times 3,0 \mathrm{~m} \\
4,0 \mathrm{~m} \times 4,0 \mathrm{~m} \\
4,6 \mathrm{~m} \times 4,6 \mathrm{~m} \\
5,2 \mathrm{~m} \times 5,2 \mathrm{~m}\end{array}$ & $\begin{array}{l}0,09 \pm 0,28 \\
0,04 \pm 0,20 \\
0,07 \pm 0,26 \\
0,04 \pm 0,19\end{array}$ & 0,095 \\
\hline & $\begin{array}{l}\text { Item 3: Hits the ball above and } \\
\text { in front of the body with the } \\
\text { dominant arm extended at the } \\
\text { moment of contact with ball. }\end{array}$ & $\begin{array}{l}3,0 \mathrm{~m} \times 3,0 \mathrm{~m} \\
4,0 \mathrm{~m} \times 4,0 \mathrm{~m} \\
4,6 \mathrm{~m} \times 4,6 \mathrm{~m} \\
5,2 \mathrm{~m} \times 5,2 \mathrm{~m}\end{array}$ & $\begin{array}{l}0,93 \pm 0,26 \\
0,97 \pm 0,17 \\
0,95 \pm 0,23 \\
0,98 \pm 0,13\end{array}$ & 0,053 \\
\hline
\end{tabular}

Note. ${ }^{*}$ Statistical difference between conditions $p<0.05$. 


\section{DISCUSSION}

The aim of the present study was to compare the tactical-technical side-out behavior between four distinct reduced volleyball game conditions with novice players. The passing results showed that the best adjustment index occurred in the condition of $3.0 \mathrm{~m} \times 3.0 \mathrm{~m}$ while the best efficiency indexes were in the situations where the courts presented larger sizes than this one. In addition, it was observed that the $4.6 \mathrm{~m} \times 4.6 \mathrm{~m}$ and $5.2 \mathrm{~m} \times 5.2 \mathrm{~m}$ conditions were positively associated with the highest decision-making score. These results highlight the importance of increasing the size of the court in SSGs, and consequently, the area/player ratio, since it seems that technical gesture is conditioned by situational constraints and momentary tactics ${ }^{20}$. Thus, possibly the results related to the adjustment of reception are due to the size of the court, since smaller dimensions require less displacement and facilitate high scores in this dimension, when considering this noninvasion sport. However, the literature shows that the increase in density, represented by the smaller space per player, results in a worse technical index in invasion sports games ${ }^{11}$, making it necessary to investigate this behavior in volleyball. In this context, our findings suggest that performing SSGs in sizes that approximate the actual area game (square footage per player) is important to maintain characteristics that emerge from the competition environment ${ }^{23}$, a fact observed in the indexes of technical and tactical analysis of passing.

Regarding the setting, we found that the $4.6 \mathrm{~m} \times 4.6 \mathrm{~m}$ and $5.2 \mathrm{~m} \times$ $5.2 \mathrm{~m}$ conditions presented the best adjustment indexes, except when it was necessary to adjust the body position according to the ball's trajectory. Moreover, considering the efficiency, it was observed that the players presented better indexes of coordination of flexion and extension of the upper and lower limbs, as well as orienting the body position to the finishing zone of attacking at the moment of contact with the ball during the $4.6 \mathrm{~m} \times 4.6 \mathrm{~m}$ and $5.2 \mathrm{~m} \times 5.2 \mathrm{~m}$ conditions compared to $3.0 \mathrm{~m} \times 3.0 \mathrm{~m}$. Decision-making analysis showed that the lowest scores were positively associated with the $3.0 \mathrm{~m} \times 3.0 \mathrm{~m}$ and $4.0 \mathrm{~m} \times 4.0 \mathrm{~m}$ conditions, while the highest score was negatively associated with the $3.0 \mathrm{~m} \times 3.0 \mathrm{~m}$ condition. These results corroborate the literature, showing that actions are interconnected in volleyball, that is, passing interferes in setting ${ }^{17,18}$, suggesting that the worst technical and tactical scores found in the $3.0 \mathrm{~m} \times 3.0 \mathrm{~m}$ situation influenced the setting. On the other hand, situational constraints imposed by different court dimensions and technical-tactical demands specific to the game scenario affect player behavior ${ }^{11,23}$.

The attacking analysis showed that the players presented better technical indexes in the $3.0 \mathrm{~m} \times 3.0 \mathrm{~m}$ condition, although the decision-making did not differ between the spatial restrictions of the game. The results suggest that the limited space may have favored the execution of technical elements of spike, considering the smaller displacement to perform the technical action. In this sense, based on ecological theory and considering 
the relationship between organisms and environment, differences in the technical aspects observed emerge from environmental constraints ${ }^{24,25}$. Technical behavior showed to be dependent on the environmental constraints imposed by changes in the playing space, thus suggesting that court size and different rules promote different behaviors, given the need to solve problems inherent to the game context and to consider tactical-technical indivisibility in volleyball performance ${ }^{26,27}$.

In summary, our findings indicate that environmental constraints and the interrelationship between game procedures promoted distinct tacticaltechnical behaviors, suggesting that the pedagogical strategy of using small-sided games for volleyball teaching should be rethought according to the objectives of teacher/coach ${ }^{3,8,9}$. Thus, the situational constraints inherent in the type of practice ${ }^{7-16}$ modify the tactical-technical behavior ${ }^{11}$ and the size of the court must be considered in the teaching and learning processes. In addition, from the ecological approach point of view, players must train and adapt to the enormous variability of actions that the context can provide in order to have more effective evolutions when experiencing these training problems ${ }^{28}$, as behaviors tactical tactics emerge from the context, the ecology of the game and possibilities for action ${ }^{29}$.

\section{CONCLUSION}

The results of this study contribute to understanding of tactical and technical behavior in novice volleyball players in different playing conditions. In this context, our findings reveal that the small games played with dimensions similar to the size of the official court are those that promote higher technical and tactical indices in the passing and setting skills. On the other hand, reduced playing area ( $4.5 \mathrm{~m} 2$ per player) results in better technical indices on the attacking skill. These findings allow us to conclude that environmental restrictions modify the tactical-technical behavior of novice volleyball players, suggesting that different ecological contexts enable actions inherent to the specific context of the game.

\section{COMPLIANCE WITH ETHICAL STANDARDS}

\section{Funding}

This research did not receive any specific grant from funding agencies in the public, commercial, or not-for-profit sectors. This study was funded by the authors.

\section{Ethical approval}

Ethical approval was obtained from the local Human Research Ethics Committee -Universidade Federal de Goiás and the protocol (no. 2.394.440) was written in accordance with the standards set by the Declaration of Helsinki. 


\section{Conflict of interest statement}

The authors have no conflict of interests to declare.

\section{Author Contributions}

Conceived and designed the experiments: Costa GDCT, Lima COV, Freire AB. Performed the experiments: Rocha ACR, Castro HO, Fonseca FS. Analyzed the data: Costa GDCT, Faria BC, Rocha ACR. Contributed reagents/materials/analysis tools: Rocha ACR, Mitre GP, Faria BC. Wrote the paper: Rocha ACR, Castro HO, Freire AB, Mitre GP, Fonseca FS, Lima COV, Costa GDCT

\section{REFERENCES}

1. Rampinini E, Impellizzeri F, Castagna C, Chamari K, Sassi A, Marcora S. Factors influencing physiological responses to small-sided soccer games. J Sport Sci 2007;25(6):659-666.

2. Capranica L, Tessitore A, Guidetti L, Figura F. Heart rate and match analysis in pre-pubescent soccer players. J Sport Sci 2001;19(6):379-384.

3. Almeida CH, Ferreira AP, Volossovitch A. Offensive sequences in youth soccer: effects of experience and small-sided games. J Hum Kinet 2013;36(1):97-106.

4. Clemente FM, Couceiro M, Martins FM, Mendes R. The usefulness of small-sided games on soccer training. J Phys Educ Sport 2012;12(1):93-102.

5. Castro HO, Costa GC, Lage GM, Praça GM, Fernández-Echeverría C, Arroyo MP, Greco PJ. Visual behavior and decision-making in attack situations in volleyball. Rev Int Med Cien Activ Fís Dep 2019;19(75):565-578.

6. Hammami A, Gabbett T J, Slimani M, Bouhlel E. Does small-sided games training improve physical-fitness and specific skill for team sports? A systematic review with meta-analysis. J Sports Med Phys Fitness 2018;58(10):1446-1455.

7. Travassos B, Gonçalves B, Marcelino R, Monteiro R, Sampaio J. How perceiving additional targets modifies teams' tactical behavior during football small-sided games. Hum Mov Sci 2014;38:241-250.

8. Ric A, Torrents C, Gonçalves B, Torres-Ronda L, Sampaio J, Hristovski R. Dynamics of tactical behaviour in association football when manipulating players' space of interaction. Plos One 2017;12(7):e0180773.

9. Bredt SGT, Morales JCP, Andrade AGP, Torres JO, Peixoto GH, Greco PJ, et al. Space creation dynamics in basketball small-sided games. Percept Mot Skills 2017;1(1):1-15.

10. Lacono AD, Martore D, Zagatto AM, Meckel Y, Sindiani M, Milic M. Effect of contact and non-contact small-sided games on elite handeball players. J Sport Sci 2016;36(1):14-22.

11. Timmerman E, Farrow D, Savelsbergh G. The effect of manipulating task constraints on game performance in youth field hockey. Sport Sci Coach 2017;12(5):588-594.

12. Bennett KJM, Novak AR, Pluss MA, Stevens CJ, Coutts AJ, Fransen J. The use of small-sided games to assess skill proficiency in youth soccer players: a talent identification tool. Sci Med Football 2017; 2(3):231-236.

13. González-Víllora S, Clemente FM, Martins FML, Pastor-Vicedo J C. Effects of regular and conditioned small-sided games on young football players' heart rate responses, technical performance, and network structure. Hum Mov 2017;18(5):135-145.

14. Evangello C, Sierra-Díaz MJ, González-Víllora S, Clemente FM. Four goals for three players':using 3 vs. 3 small-sided games at school. Hum Mov 2019;20(4):68-78. 
15. Ometto L, Vasconcellos FV, Cunha FA, Teoldo I, Souza CR, Dutra MB, et al. How manipulating task con- straints in small-sided and conditioned games shapes emergence of individual and collective tactical behaviours in football: a systematic review. Int J Sports Sci Coach 2018;13(6):1200-1214.

16. Serra-Olivares J, González-Villora S, Garcia-López LM, Araújo D. Game-based approaches' pedagogical principles: exploring task constraints in youth soccer. J Hum Kinet 2015;46:251-261.

17. Costa GCT, Afonso J, Barbosa RV, Coutinho P, Mesquita I. Predictors of attack efficacy and attack type in high-level brazilian women's volleyball. Kinesiology 2014;46(2):242-248.

18. Loureiro M, Hurst M, Valongo B, Nikolaidis P, Laporta L, Afonso J. A Comprehensive Mapping of High-Level Men's Volleyball Gameplay through Social Network Analysis: Analysing Serve, Side-Out, Side-Out Transition and Transition. Monten J Sports Sci Med 2017; 6(2): 35-41.

19. Ericsson A, Charnes N, Feltovich P, Hoffman R. The cambridge handebook of expertise and expert performance. New York: Cambridge University Press; 2006.

20. Collet C, Nascimento JV, Ramos V, Stefanello JMF. Construction and validation of a technical-tactical performance evaluation instrument in volleyball. Rev Bras Cineantropom Desempenho Hum 2011;13(1):43-51.

21. Porath M, Vieira J, Milisted M, Quinaud R. Level of technical-tactical performance of youth volleyball teams. Motrici 2016;12(2):8-17.

22. Tabachnick B, Fidell L. Using multivariate statistics. 6th ed. Boston: Allyn \& Bacon; 2013.

23. Jara D, Ortega E, Gómez MÁ, de Baranda PS. Effect of Pitch Size on Technical-Tactical Actions of the Goalkeeper in Small-Sided Games. J Hum Kinet 2018;62:157-166. doi:10.1515/hukin-2017-0167

24. Seifert L, Araujo D, Komar J, Davids K. Understanding constraints on sport performance from the complexity sciences paradigm: an ecological dynamics framework. Hum Mov Sci 2017;56:178-180.

25. Davids K, Araújo D, Hristovski R, Serre NB, Button C, Passos P. Complex systems in sport. Routledge, Taylor \& Francis Group, London, UK; 2014.

26. Araújo R, Mesquita I, Hastie P, Pereira C. Students' game performance improvements during a hybrid sport education-step-game-approach volleyball unit. Eur Phys Educ Rev 2016;22(2):185-200.

27. Araújo R, Hastie P, Lohse KR, Bessa C, Mesquita I. The long-term development of volleyball game play performance using Sport Education and the Step-GameApproach model. Eur Phys Educ Rev 2019;25(2):311-326.

28. Dias G, Mendes P, Santos J, Gama J, Mendes R, Menayo R, et al. Cognition and action: an ecological perspective in sport. Eur J Hum Mov 2015;35:137-147.

29. Araújo D, Hristovski R, Seifert L, Carvalho J, Davids K. Ecological cognition: expert decision-making behaviour in sport. Int Rev Sport Exerc Psych 2017;12(1):1-25.

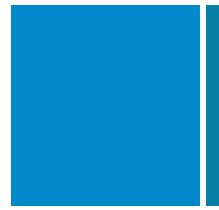

Corresponding author

Gustavo De Conti Teixeira Costa

Faculdade de Educação Física e Dança

Universidade Federal de Goiás, Campus Samambaia

Avenida Esperança s/n, Goiânia, Goiás, Brasil. CEP: 74.690-900.

E-mail:conti02@ufg.br 